\title{
Tax Incentives for Investment in Intensive Forestry
}

\author{
A study by Working Group \#9: Policy \& Economics \\ Canadian Institute of Forestry
}

\begin{abstract}
The National Executive Committee of the Canadian Institute of Forestry was asked by the federal Minister of Fisheries and the Environment to propose and detail specific federal tax incentives for intensified forestry. Estimates and analyses of Canada's present timber supply show that most timber surplus is remote and costly, and emphasize the need for regular and systematic renewal on productive forests in order to maintain the forest industry. Regeneration has not kept pace with depletion, and a backlog of $12 \%$ of the productive forest land in Canada now requires treatment. Moreover, serious annual shortfalls in current provincial reforestation programs, are steadily adding to this area. The responsibility for restocking these depleted forest lands rests with those who benefit from productive forests. The federal government is asked to cooperate by changing the Income Tax Act and Regulations to encourage forest operators to invest in current reforestation activities, and by negotiating long-term costsharing agreements with provincial governments to attack the backlog.
\end{abstract}

\section{Objectives/Reasons for Study}

The National Executive Committee of the Canadian Institute of Forestry met with the Minister of Fisheries and the Environment, Romeo Leblanc in February, 1977 to review a letter presented to him on national forestry matters. During the discussion the Minister showed considerable interest in tax incentives by the Government of Canada for investment in intensive forestry, and asked the group to return to him with more details.

In April, 1977, the Executive Committee asked Working Group \#9: Policy and Economics "to draft a proposal for tax incentives to encourage and intensify good forestry practices in our country." A study group was formed consisting of Messrs. Jim Clark, Jack Ker, Glenn Manning, Tony Sayle and Ms. Fran Wetton, together with several 'unofficial' members; and the report following is the result of their investigations and discussion.

\section{Scope of this Report}

Forest management includes silvicultural treatment of forest land to encourage healthy, vigorous stands of desirable tree species which use the land efficiently to produce economic crops or other benefits. Treatment involves site preparation, prompt regeneration, spacing, thinning, protection and other practices to improve the site, tree and stand. From this wide spectrum of forestry practices the committee has narrowed its study to regeneration, the basic requirement for renewing the resource, because they consider the major problem common to all provinces is the serious shortfall in forest replacement. This is not to suggest that other silvicultural activities are not important, but rather it is necessary to begin with the obvious. Additional measures can be incorporated without altering the methods proposed.

\section{Canada's Timber Supply}

A comprehensive survey of Canada's timber supply was published in 1973 (F.L.C. Reed and Associates 1973) and further adjusted in 1978 (F.L.C. Reed and Associates 1978). Table 1 summarizes the annual allowable cut under sustained yield management, average harvest, and apparent physical reserves of timber by province. These volumes, however, must be reduced by more than $50 \%$ to allow for inaccessible forests. In addition, the 1978 study found that local timber shortages existed throughout Canada, since a surplus in one area could not always be transported economically to a deficit locality. Further, increased costs could be expected in harvesting and manufacturing fibre from these generally unattractive surplus areas because of decreased wood quality and volumes per acre, and greater distances to mills and markets.

Timber supplies can be augmented both by intensified forest management practices which include regeneration, and by increased utilization of fibre, on accessible productive forests. While this report deals only with the former, it should be noted that closer utilization of fibre presents relatively high-cost alternatives for obtaining additional supplies.

From these estimates and analyses of Canada's timber supply it is apparent that in order to maintain an economic supply of timber for established industry, the forests on accessible, productive forest land must be regularly and systematically renewed. Any future industrial expansion will require additional forestry practices to increase yields.

\section{Forest Regeneration in Canada}

The National Regeneration Conference held in Quebec City on October 19-21, 1977 provided our study group with the most recent statistics and timely analyses of the state of the art in Canada.

In preparation for this conference, reports were submitted from all provinces and from foresters across Canada. A dismal regeneration picture emerged. Canada is considered to be still in the 
Table 1. - Annual allowable cut and reserve timber supply, by province.

\begin{tabular}{|c|c|c|c|c|}
\hline \multirow[b]{2}{*}{ Province } & \multirow{2}{*}{$\begin{array}{c}\text { Annual } \\
\text { Allowable Cut }\end{array}$} & \multirow{2}{*}{$\begin{array}{l}\text { Average } \\
\text { Harvest }\end{array}$} & \multicolumn{2}{|c|}{ Reserve Timber Supply } \\
\hline & & & Accessible & Inaccessible \\
\hline 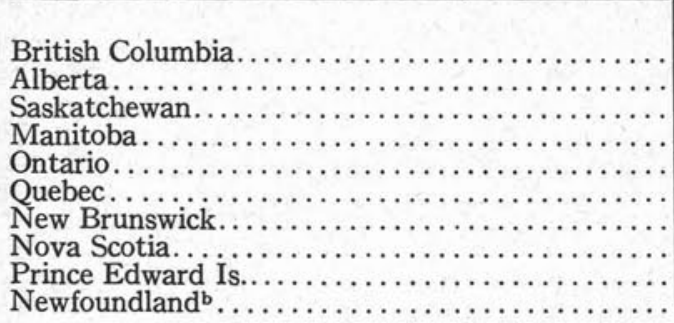 & $\begin{array}{r}000 \mathrm{M}^{3} \\
99,365 \\
24,916 \\
7,752 \\
7,556 \\
43,163 \\
52,905 \\
9,093 \\
4,645 \\
398 \\
6,513\end{array}$ & $\begin{array}{r}68,152 \\
6,784 \\
2,840 \\
2,079 \\
24,981 \\
34,850 \\
9,300 \\
3,860 \\
187 \\
3,350\end{array}$ & $\begin{array}{c}15,065 \\
13,409 \\
3,392 \\
3,523 \\
14,969 \\
3,405 \\
(207)^{\circ} \\
785 \\
210 \\
1,967\end{array}$ & $\begin{array}{r}16,148 \\
4,723 \\
1,520 \\
1,954 \\
3,213 \\
14,650 \\
\overline{-} \\
1,196\end{array}$ \\
\hline
\end{tabular}

a) Average of 2 best years 1973-75.

b) Includes Labrador.

Source: F.L.C. Reed and Associates 1978.

exploitive stage on much of its public forest lands (estimated to be $90 \%$ of the total Canadian forest land), where little or no management is practiced apart from protection (F.L.C. Reed 1977). Some forests are sufficiently resilient to renew themselves in a reasonable time with little or no help from man, but much forest land requires some form of artificial regeneration to ensure adequate stocking of a commercial crop.

Most provincial governments have initiated programs to restock logged and ravaged Crown forests, but reports show that no where is reforestation keeping pace with depletion; indeed, the backlog of poorly stocked forest lands in some provinces is staggering. It has been estimated that Canada has over 70 million acres of cutover and burned forest land which require treatment (Weetman 1977). This is $12 \%$ of the total productive forest land used for forestry purposes. Moreover, this depleted forest land is increasing at an annual rate of $0.7 \%$ due to a shortfall in present provincial reforestation programs.

These sobering facts mean that we are not catching up but are falling further behind each year in renewing the forest resource, and emphasize the need for immediate concerted effort if Canada is to maintain its present level of forest production and remain competitive in international markets.

\section{Responsibility for Reforestation}

It is not difficult to fix the blame for much of the unproductive forest land in Canada, and to glibly point a finger at those who caused it. Past performance by the private sector, and the provincial governments' failure to control these activities and to make provision for funding forestry programs from operational accounts, are both liable for the huge regeneration backlog (Crossley 1976). Where was the forestry profession when this sorry record was being written, was a legitimate question at the recent Regeneration Conference (F.L.C. Reed 1977). To dwell on historical failure, however, has little relevance in working toward a solution. Responsibility for reforestation, at this point, should be shared by those who benefit from maintaining productive forests in Canada.

Who benefits from timber-producing forests? Certainly the 1.3 million Canadians $111 \%$ of the labor force) employed directly in forest industries, and the many thousands more who derive income indirectly, are concerned. The returns from investment in both large forestry complexes and small sawmills are of great interest to shareholders and owners. All Canadians benefit from the healthy revenues returned to governments by forestry activity: $\$ 1,000$ million each year to the federal government, and $\$ 650$ million each year to provincial governments. In a trade-dependent country such as ours all Canadians should be vitally interested in the future of our major exports, forest products, which constitute $18 \%$ of the value of all exports.

It is obvious that unless there is a significant increase in reforesting cut-over and ravaged forest land (or other intensified forestry activities to increased yields), the base from which all this wealth is derived will shrink steadily.

As owners of provincial Crown forests, the provincial governments have primary responsibility for forest renewal. However, while the federal government has no legal responsibility, it has vested interest in maintaining an industry which employs a large labor force and generates a great deal of public revenue. A modest $8 \%$ of this annual billion-dollar revenue is currently being used to fund the services and facilities of the Canadian Forestry Service ( $\$ 34$ million per year), and various grants and affiliated projects (an additional $\$ 30-40$ million per year). Forest industry, too, benefits from an assured supply of raw material at an economic price, and should share in the cost of maintaining the resource.

Other countries have responded to the need for reforestation with a variety of government incentives. Steenberg (1976) cites France, with its low interest loans for reforestation, and New Zealand, in which large plantations were developed through a scheme to reduce unemployment.

In the United States, the important incentive to intensive forestry is the capital gains tax, which, since it was first applied to timber in 1944. 
has resulted in a significant increase in reforestation (Condrell 1975). The United States has other incentive programs (Mills 1976) such as the Forestry Incentive Program and the Cooperative Forest Management Program.

The Nordic countries of Sweden and Finland differ in their approach to incentives, but both operate through the tax system. Finland, to give tax-free benefit to intensive forestry, taxes income on a land productivity basis (Williams and Canham 1972, Price Waterhouse and Co. 1973). Sweden provides incentives for intensive forestry through an investment reserve (Price Waterhouse and Co. 1973), which generates tax benefits, and through direct subsidies.

The applicabiliy of this assortment of measures to Canadian conditions has not been well established. Each is the result of specific conditions of government and resource. They do, however, present a broad range of options which might be explored.

\section{The Cooperation of the Federal Government in Reforestation}

The federal government can respond to the challenge in Canada in several ways. Tax incentives for current reforestation can be introduced directly into the stream of revenue from industry to the federal Department of Finance. And the only way to retire the formidable backlog of regeneration needs is by the major assault of a long-term shared-cost agreement between federal and provincial governments. Jointly-funded programs of this kind have proved successful in the past. They should not be confused, however, with present short-term grants (DREE) to eastern provinces for forest management programs in economically depressed areas.

\section{Federal Tax Incentives for Reforestation}

The study group examined the Canadian Income Tax Act and Regulations 1976-77 for effective ways of introducing incentives for regeneration. Two forms of tenure are recognized in the Act: a Timber Resource Property, i.e., a tenure that is subject to renewal (Sec. 13(21) (d(1))) and the converse, a Timber Limit and Cutting Right, i.e., a tenure which is not a Timber Resource Property. Within the Act, a lessee of provincial Crown land under forest management agreement controls a Timber Resource Property, while a private forest owner managing his land for timber production owns a Timber Limit. Salvage sales and some types of timber sale are Cutting Rights and are considered non-existent once the timber has been liquidated.

The obligations of the taxpayer (an individual or organization) are systematically outlined in the legislation. Adjustments are made to gross income to take account of expenditures which are expensible, and capital expenditures which may or may not be subject to depletion or depreciation allowances. This results in a taxable income on which taxes are paid according to current rates.

It was found that most expenditures associated with intensive forestry, including reforestation, are deductible either as expenses or as capital expenditures subject to depletion or depreciation. An expense is deemed deductible if it was made for the purpose of gaining or producing income (Sec. 18(1))a)), and was "reasonable in the circumstances" (Sec. 67). Private forest owners can thus legitimately deduct as expenses all reforestation costs. On leased provincial Crown land where reforestation is a requirement of the contract in managing the resource for timber, reforestation is obviously an expense of staying in business. Other cases are less clear.

Capital expenditure deductions are fairly complex. Depletion (based on a production rate) or depreciation (based on time) allowances are applicable to the timber limit or cutting right itself, to roads, machinery and other capital. The undepreciated capital cost of a timber resource property may be written off at a rate of $15 \%$ per year. The study group noted that the current depreciation allowance policy is based on the original cost of the capital asset and should more realistically allow for the inflated cost of replacement assets. ${ }^{1}$ Also, the accelerated depreciation currently allowed the manufacturing and processing sectors to stimulate employment or environmental protection could be applied to the logging sector to stimulate intensive forestry in Canada. ${ }^{2}$

Whether reforestation costs fall under expense or are allowed as part of depletion or depreciation in capital expenditures, the calculation of taxable income and resulting tax payable still show that any expenditure is shared by the taxpayer and by the federal government (in decreased revenue). If the tax rate is $40 \%$, the taxpayer is liable for $60 \%$ of his reforestation costs and the federal government indirectly for $40 \%$. Under the current system there is little incentive for the taxpayer to reforest provincial Crown lands since every dollar spent on reforestation decreases company profits. Most lessees today only invest in obligated requirements related to resource renewal because of the uncertainty of tenure and political change. The stumpage off-set for "forestry costs" made by some provincial governments for intensified forestry activities will be considered in a later section.

Investment tax credits (Sec. 127(5)) are applied after the tax payable has been collected. Tax credits are determined as a per cent of a selected expenditure, and provide an immediate reduction in taxes otherwise payable, and increased cash flow to the taxpayer. They are applicable to a wide range of investments such as buildings, machinery, and processing equipment, as well as exploring for oil and prospecting for minerals; but unfortunately this section of the Act appears to exclude investment in forestry. Were such a tax system introduced it would represent a considerable inducement to invest in reforestation. The

1 Personal communication, J. D. Clark. 2 Ibid. 
difference between the present expensing provisions for reforestation and the proposed tax credit system is in the additional cash returnable to the taxpayer at the time that taxes are paid. For a given level and cost of reforestation the taxpayer in both systems would share the expense with the federal government, but in the tax credit case would have an additional sum rebated which could be used for forestry investment. Adjustments in the tax credit rate could bring about any desired reforestation, including all costs borne by the federal government.

There are many advantages of the investment tax credit method as an incentive for reforestation. Not only is it relatively easy to introduce and to administer, but it allows for greater control over reforestation expenditures than straight expensing. One can assume that the taxpayer claiming a tax credit has not only an economically viable business but must be reasonably efficient, and operating on average or better-than-average forest land. This system would tend to finance reforestation of better sites first (desirable from both forestry and economic points of view) without the need for directives or monitoring. Also, where the taxpayer has not been required heretofore to reforest his own land or Crown land in a contract with a provincial government, he may now actively seek to involve himself in this activity if there is sufficient incentive.

It has also been suggested ${ }^{3}$ that tax credits be allowed for employing suitable social welfare recipients in reforestation. These people would be paid the normal pay rate for the work done, and industry, in turn, would be reimbursed at the normal welfare payment rate by federal or provincial government, as a tax credit.

The group also studied the legislation under "Allowance for oil or gas well, mine or timber limit" (Sec. 65(1)), and not to be confused with depletion and depreciation allowances in capital cost (Sec. 20(1)(a)). The regulations for this section provide for deductions for development involved in the operation of oil and gas wells and mines, but are strangely silent on timber limits stated in the title. A parallel section in the regulations might be introduced to recognize the current depleting base of timber.

3 Ibid.

\section{Federal - Provincial Agreements for Reforestation}

The task of reforesting the backlog of denuded forest lands in Canada should be part of a major cost-sharing agreement between federal and provincial governments. Foresters generally agree that the best sites should be planted first since these promise the best returns. In view of industrial and regional development and future requirements for fibre, the plan should be approached on a province by province basis, thus allowing each province to direct its attention to a combination of factors regarding site and regional development.
Mature timber values per acre vary greatly across Canada, so do reforestation costs. With these differences the problem of distributing federal grants equitably would appear formidable. However, if a given budget is apportionated on the basis of restocking a given per cent of the backlog of commercial forest land acreage requiring reforestation in each province, each province would be treated at a rate that would complete the job in all provinces at the same time. The actual planting should be administered by provincial agencies (in the manner of each province), in order to prevent duplication of facilities and work force. Provincial governments would, of course be required to maintain their previous reforestation levels, and to share in the additional reforesting under consideration. In this way all provinces would be helped equally to restock depleted forests.

In reaching agreement on sharing costs of reforestation between federal government, provincial governments and the industry, a thorough analysis of all reasonable costs associated with renewing the resource should be made. At present there appear to be many overlapped areas, for example, the aforementioned stumpage off-set of "forestry costs" allowed in some provinces. By reducing stumpage revenues the provinces are, in effect, paying a part of these reforestation costs, as well as other more apparent ones. It is not clear whether the various reforestation costs reimbursed by reduced stumpage are also eligible as expenses in income tax calculation. The whole field of cost sharing must be clarified before an equitable plan can be implemented.

\section{References}

Condrell, W. K. 1975. "Trends in timber taxation." Forest Farmer 35(2): 10-11; 40.

Crossley, D. I. 1976. The case for industrial management of Canada's forest land. H. R. MacMillan Lectureship, Univ. B.C., Vancouver.

F.L.C. Reed. 1977. Forest management in Canada and its promise for the future. Presented to the National Regeneration Conference, October 19-21, 1977, Quebec.

F.L.C. Reed and Associates. 1973. Canada's reserve timber supply. Dept. of Industry, Trade and Commerce, Ottawa.

F.L.C. Reed and Associates. 1978. Forest management in Canada, Vol. I. Can. For. Serv., Inf. Rpt. FMR-X-102.

Mills, T. J. 1976. Cost effectiveness of the 1974 forestry incentives program. U.S.D.A., Forest Service. Res. Pap. $\mathrm{R},-175$.

Price Waterhouse and Co. 1973. A study of taxation practices related to the pulp and paper industry. Dept. of Industry, Trade and Commerce, Ottawa.

Steenberg, B. K. 1976. "The Northern Coniferous forest, a primary source of world resources, can Canada meet the growing challenge of expanding world demands?". For. Chron. 52:255-262.

Weetman, G. F. 1977. Forest regeneration in Canada. Presented to the National Regeneration Conference, October 19-21, 1977, Quebec.

Williams, E. T. and H. O. Ganham. 1972. "The productivity concept in forest taxation." For. Sci. 18:3-20.

J. D. Clark J. W. Ker

G. H. Manning

A. C. Sayle

E. A. F. Wetton, Chairman 